\section{Biofumigation Performance of Four Brassica Crops in a Green Chile Pepper (Capsicum annuum) Rotation System in Southern New Mexico}

\author{
Rachel E. Rudolph ${ }^{1}$ \\ Plant and Environmental Sciences, New Mexico State University, P.O. Box \\ 30003, MSC 3Q, Las Cruces, NM 88003
}

Carl Sams ${ }^{2}$

Department of Plant Sciences, University of Tennessee, Knoxville, Tennessee

Robert Steiner ${ }^{2}$

Economics, Applied Statistics, \& International Business Department, New Mexico State University, NM

Stephen H. Thomas ${ }^{2}$

Department of Entomology, Plant Pathology, and Weed Science, New Mexico State University, NM

Stephanie Walker ${ }^{3}$

Department of Extension Plant Sciences, New Mexico State University, NM

Mark E. Uchanski ${ }^{4,5}$

Plant and Environmental Sciences, New Mexico State University, P.O. Box 30003, MSC 3Q, Las Cruces, NM 88003

Additional index words. cover crop, mustard, soil management, nematode

\begin{abstract}
Biofumigation is a sustainable method of soil management in cash crop rotations that can increase soil organic matter (SOM), moderate soil $\mathrm{pH}$, suppress weeds and soilborne pathogens through glucosinolates (GSL), and increase water infiltration. This 2-year (2011-13) field study evaluated four different Brassica crops for their biofumigant potential in a chile pepper rotation system in southern New Mexico. The four cultivars included: three mustards (Brassica juncea 'Caliente 61', 'Caliente 199', and 'Pacific Gold') and one broccoli (Brassica oleracea var. botrytis 'Arcadia'). As a result of concerns that these mustards could be hosts for nematodes, a greenhouse study was conducted in the second year to evaluate the biofumigant crops for their southern root-knot nematode (Meloidogyne incognita, RKN) host suitability and their seedling establishment in the presence of RKN. In Year 1 (2011), conditions were ideal, which resulted in high mustard biomass production and, consequently, significantly higher SOM and lower $\mathrm{pH}$ than the bare soil control plots. However, there were no chile pepper yield differences among treatments. Conditions were much less favorable in Year 2 and the resultant poor biomass production did not cause an increase in SOM as seen in Year 1. In the RKN greenhouse study, broccoli was the least susceptible biofumigant crop. After one nematode generation (683 cumulative heat units), RKN populations were less than half of the original inoculum level on the broccoli. However, RKN populations increased in the presence of 'Caliente 61', 'Caliente 199', and 'Pacific Gold'. Overall, broccoli produced lower biomass and lower GSL concentrations than the mustard treatments but may be a valuable crop for growers with nematode issues because RKN populations decreased in its presence. Based on high biomass production and high GSL concentration, 'Caliente 199' showed the most potential as a biofumigant crop for southern New Mexico.
\end{abstract}

The use of cover crops in rotation with a cash crop is one way to maintain and build SOM (Magdoff and Van Es, 2009). Cover crops are plants grown for the specific purpose of maintaining or improving soil characteristics (Magdoff and Van Es, 2009). Any groundcover planted before, after, or concurrently with the cash crop and then ended before the next crop is seeded may be erosion, increase water infiltration, decrease nutrient loss by leaching, attract beneficial insects, suppress weeds, and/or suppress soilborne pathogens (Magdoff and Van Es, 2009).

In New Mexico, where chile pepper (Capsicum annuum L.) production is the second highest in the country $(58,967 \mathrm{t}$ in 2013) (U.S. Department of Agriculture National Agricultural Statistics Service, 2014), there are many obstacles to overcome such as low SOM $(0.5 \%$ to $1.0 \%)$ and high $\mathrm{pH}(7.5$ to 8.0 ). Many growers also face issues with weed competition and soilborne pathogens (Bosland and Votava, 2000). Chile wilt diseases such as those caused by Phytophthora capsici and Verticillium dahliae can result in devastating yield losses (Walker et al., 2012). Once established, soilborne pathogens can be especially difficult to manage. For this reason, many growers nationwide have adopted the use of various chemical fumigants such as methyl bromide, metam sodium, metam potassium, chloropicrin, or 1,3 dichloropropene (Telone $^{\mathrm{TM}}$; Dow AgroSciences, Indianapolis, IN) to suppress yield-detracting weeds and pathogens such as fungi and nematodes (Collins et al., 2006; Martin, 2003).

Synthetic chemical fumigation is a conventional approach to soilborne pathogen management. Many New Mexico chile pepper farmers also rely heavily on the fumigant chloropicrin to reduce soilborne pathogens (Walker et al., 2012). Managing soilborne pests presents many challenges, and chemical fumigation is one of the few choices available to growers. However, the use of chemical fumigants is costly for farmers and results are often inconsistent. Use of chemical fumigants in California can cost growers from $\$ 6600$ to $\$ 7400$ per hectare (University of California Agriculture and Natural Resources, 2013). A study conducted in Arizona in 2009 found no significant difference in chile pepper stand establishment or seedling vigor between plots treated with chemical fumigants and untreated plots (Walker et al., 2012). Many chemical fumigants can effectively suppress pathogens, but several of the active compounds are harmful to the environment as well as to humans. For example, methyl bromide is a significant ozone-depleting substance and can also cause various health problems ranging from skin and eye irritation to death (U.S. Environmental Protection Agency, 2000; US-EPA, 2014). For these reasons, methyl bromide was phased out of use in the United States as of January 2005 by the Environmental Protection Agency (EPA), except in cases of quarantine and preshipment and critical use exemptions (US-EPA, 2014). Because of their potential dangers, the EPA is also regulating or restricting other commonly used soil fumigants (US-EPA, 2012). As a result, alternatives to chemical fumigants are needed.

Biofumigants are a type of cover crop that, in addition to other soil benefits, have the ability to suppress soilborne pathogens including fungi or nematodes (Kirkegaard et al., 1999). Biofumigation is a sustainable method of soil management in cash crop 
rotations that may present additional options for conventional and organic growers. Biofumigants are biologically active (bioactive) cover crops and are frequently referred to as green manures because they are incorporated into the soil as living plant material (Kirkegaard et al., 1999). The term biofumigation refers to the suppression of soilborne pests and pathogens using naturally occurring biocidal compounds, particularly isothiocyanates (ITCs), which are released from bioactive Brassicaceous cover crops on hydrolysis of GSLs (Kirkegaard and Sarwar, 1998). ITCs are chemically similar to methyl isothiocyanate, the active agent from the chemical fumigant metam sodium (Matthiessen and Kirkegaard, 2006).

GSLs are secondary, defensive, antiherbivory compounds that occur in members of the Brassicaceae family (Kirkegaard and Sarwar, 1998). Concentrations of GSLs and the various hydrolysis products vary within each species and within cultivars; therefore, not all Brassica species are well suited as a biofumigant cover crop (Kushad et al., 1999). There are $\approx 20$ different types of GSLs found in Brassica species, and their structures vary based on the organic side chain (aliphatic, aromatic, or indolyl) (Kirkegaard and Sarwar, 1998). When GSLs are hydrolyzed by the endogenous enzyme myrosinase, there are several possible products depending on the soil $\mathrm{pH}$ : oxazolidinethiones, nitriles, thiocyanates, and many forms of ITCs (Kirkegaard and Sarwar, 1998). ITCs are typically the most active and the most toxic of the hydrolysis products (Brown and Morra, 1997). However, the toxicity level of different ITCs to different organisms varies (Kirkegaard and Sarwar, 1998).

Unlike chemical fumigants, biofumigants, taken as a whole, may also have the added benefit of increasing SOM by $8 \%$ to $23 \%$, suppressing weeds by up to $40 \%$, and increasing soil water infiltration 2- to 10 -fold (Collins et al., 2006; Mattner et al., 2008; McGuire, 2003). In addition to these agronomic benefits, biofumigant crops may also be a more economically viable choice for

Received for publication 12 June 2014. Accepted for publication 27 Oct. 2014.

Funding for this research was provided by the New Mexico Chile Association. Additional salaries and research support were provided by state and federal funds appropriated to the New Mexico Agricultural Experiment Station.

We thank Ms. Jacqueline Beacham for her assistance with the nematology aspect of this study. We acknowledge the technical assistance of Mr. Mike Petersen and Ms. Luz Hernandez. We also thank Curry Seed and Chile Company (Pearce, AZ) for the pepper seed donations and High Performance Seed (Moses Lake, WA) for the mustard seed donations.

${ }^{1}$ Graduate Research Assistant.

${ }^{2}$ Professor.

${ }^{3}$ Assistant Professor

${ }^{4}$ Associate Professor.

${ }^{5}$ To whom reprint requests should be addressed; e-mail uchanski@nmsu.edu. farmers than chemical fumigants. For example, farmers could save \$163/ha using green manures, including Brassicas, instead of chemical fumigants (McGuire, 2003). There is the potential for rapid adoption of cover crops that are effective at reducing a major input cost like fumigation and also improving the cash crop health and productivity (Snapp et al., 2004).

The ideal biofumigant crop would therefore have high GSL content in the tissues and also high biomass production to maximize the amount incorporated into the soil (Kirkegaard et al., 1999). Another factor that may be considered when selecting for biofumigant potential is the ability to harvest a primary product such as broccoli or Brussels sprouts, whose residues can then be incorporated into the soil as a biofumigant. This strategy has the benefit of additional income but the drawback of reduced biomass for biofumigation purposes. Biofumigant crops should also be a non-host for nematodes or able to suppress nematode populations in the field.

Southern RKN (Meloidogyne incognita), a plant-parasitic nematode, is of great concern to chile pepper growers in southern New Mexico (Walker et al., 2012). This species is commonly found in the southwestern United States where chile peppers are cultivated and is a serious pathogen that can reduce yields by more than $40 \%$ (Thomas, 1995 ; Thomas et al., 1995). Chile pepper growers may experience reduced plant vigor, yield loss, or complete loss of production by seedling death, depending on the crop's stage of development (Goldberg, 2001). The use of mustards, both Brassica and Sinapsis species, as bioactive cover crops is becoming common practice with potato growers in Washington to suppress plant-parasitic nematodes (Ramirez et al., 2009). An 8-week field trial in northern Australia found that 'Weedcheck' fodder radish (Raphanus sativus) was resistant to Meloidogyne sp. and caused a reduction in the nematode population (Pattinson et al., 2007). A field study in the Czech Republic observed that after incorporating brown mustard and covering it with polyethylene sheets, the number of root galls in carrots (Daucus carota) caused by northern RKN (Meloidogyne hapla) decreased (Douda et al., 2012).

A particular biofumigant crop may work well in a certain geographical area with a specific set of issues (pathogens, nematodes, etc.) and a location-specific primary crop but may not perform as expected in another region with a different crop-pest interaction. The soil environment is complex and varies from state to state, field to field, and even within a field. Individualized evaluation is necessary to determine the impacts biofumigants have on different vegetable cropping systems. In southern New Mexico, little is known about the interaction between biofumigants and the soil, pests, and region-specific crops such as chile pepper.

The primary objective of this research was to evaluate the biofumigation performance of four Brassicas including three mustard cultivars (Brassica juncea 'Caliente 61', 'Caliente 199', 'Pacific Gold') and one broccoli cultivar (Brassica oleracea var. botrytis 'Arcadia') in the semiarid climate of southern New Mexico. Biofumigant performance was evaluated based on biomass production and GSL concentrations in Brassica crop tissues; soil changes, including $\mathrm{SOM}$ and $\mathrm{pH}$; and chile pepper crop performance, including stand establishment, yield, and vegetative biomass. A second objective of this research was to conduct a greenhouse biofumigant seedling establishment study and a host assay to evaluate the growth and host suitability of the biofumigant species to RKN.

\section{Materials and Methods}

The present study was conducted in the 2011-12 (Year 1) and 2012-13 (Year 2) growing seasons at New Mexico State University (NMSU) Fabian Garcia Science Center (FGSC) (lat. $32.28^{\circ} \mathrm{N}$, long. $106.77^{\circ}$ $\mathrm{W}, 1186 \mathrm{~m}$ elevation) located in Las Cruces, NM. The experiment was arranged as a randomized complete block design with five replications. This project was a 2 -year, short cycle rotation of biofumigants and chile pepper. Biofumigant treatments were overlaid in the same location in both years using permanent markers to identify treatment locations for the purpose of identifying possible carryover effects from 1 year to the next and to avoid treatment combinations that were beyond the scope of the study. Before this experiment, cayenne pepper (Capsicum annuum 'Mesilla') was grown in the field followed by field pea (Pisum sativum L.) as a green manure. To establish baseline soil characteristics, a composite soil sample was taken at $16.5-\mathrm{cm}$ depth and submitted to the NMSU Soil, Water, and Agricultural Testing Laboratory (SWAT) in Aug. 2011. The test classified the soil as a sandy loam, with $\mathrm{pH} 7.8,0.9 \%$ organic matter, electrical conductivity of $1.79,15.5 \mathrm{ppm}$ of nitrate, $39.7 \mathrm{ppm}$ of phosphorus, and $77.0 \mathrm{ppm}$ of potassium. Every attempt was made to manage the field under organic certification guidelines for the duration of the study.

Land preparation in the fall of 2011 and 2012 consisted of plowing, leveling, and preparing beds in a northwest to southeast orientation with furrows for flood irrigation of the biofumigant crops. Each treatment plot consisted of three rows with a total area of $11.6 \mathrm{~m}^{2}(7.6 \mathrm{~m} \times 1.5 \mathrm{~m})$ per treatment block. Buffer areas $0.6 \mathrm{~m}$ long were established between each block in the same row. Rows were spaced $1.02 \mathrm{~m}$ apart for both the biofumigant crops and the primary crop.

Four biofumigant crop species were planted in the fall of each year in addition to a bare soil control. The four biofumigant crops included Brassica juncea 'Pacific Gold', 'Caliente 199', and 'Caliente 61' and Brassica oleracea var. botrytis 'Arcadia' 
(broccoli). 'Caliente 199' and 'Caliente 61' were obtained from High Performance Seeds, Inc. (Moses Lake, WA). 'Pacific Gold' and 'Arcadia' were purchased from Johnny's Selected Seeds (Winslow, ME).

Year 1. 'Arcadia' broccoli was seeded on 12 Aug. 2011 in flats of 72 cells (TLC Polyform, Inc., Plymouth, MN) and grown in a greenhouse with only ambient light and temperature of 22.2 to $23.3{ }^{\circ} \mathrm{C}$. On 16 Sept., the flats were moved to a lath house to harden. Broccoli plants were fertilized weekly using fish emulsion $(5 \mathrm{~N}-1 \mathrm{P}-1 \mathrm{~K}$; Lilly Miller ${ }^{\circledR}$ Alaska, Walnut Creek, CA) until they were transplanted into the field on 30 Sept. with 20.32-cm spacing between each plant and two rows spaced $15.24 \mathrm{~cm}$ apart on each bed. 'Pacific Gold' and 'Caliente 61' were broadcast at a rate of $6.74 \mathrm{~kg} \cdot \mathrm{ha}^{-1}$ and 'Caliente 199' at a rate of $11.23 \mathrm{~kg} \cdot \mathrm{ha}^{-1}$ according to the supplier's guidelines. To ensure even distribution, seed was mixed with $\approx 2$ L of peatmoss potting mix (LM-3; Lambert Peat Moss, Inc., Quebec, Canada) before sowing into each block. The mustard seed and peatmoss mix was broadcast onto bed tops, lightly raked to ensure soil contact, and flood-irrigated on 1 Sept.

Impact sprinklers with $1.9-\mathrm{cm}$ nozzles (35A; Rain Bird Corporation, Azusa, CA) were installed on 8 Sept. to wet the surface of the beds and aid in the germination and emergence of the mustard seedlings. After emergence, the field was flood-irrigated once a week during the fall to ensure adequate moisture. Based on soil test results, 317 $\mathrm{kg} \cdot \mathrm{ha}^{-1}$ of fertilizer $\left(10 \mathrm{~N}-2 \mathrm{P}-6 \mathrm{~K}\right.$; Ringer $^{\circledR}$ Lawn Restore ${ }^{\circledR}$, Woodstream Corp., Lititz, PA) was side-dressed by hand on 18 Oct.

To evaluate biofumigant performance, biomass was collected by pulling entire plants (roots, shoots, stems, flowers) out of the soil from a $2-\mathrm{m}$ portion of the center row on 10 Nov. Each 2-m sample was collected after measuring $1 \mathrm{~m}$ in from the north edge of the center row to avoid edge effects. Fresh weight was taken for each sample, then plants within each sample were chopped and mixed, and a representative subsample was collected and weighed for future GSL analysis. The remainder of each original sample was oven-dried at $39^{\circ} \mathrm{C}$ for $10 \mathrm{~d}$ and then weighed. Subsamples were weighed fresh and then frozen at $-20{ }^{\circ} \mathrm{C}$. Beginning on 18 Nov., subsamples were lyophilized (VirTis Freezemobile 25XL; SP Scientific, Warminster, PA) for $\approx 5 \mathrm{~d}$ and then weighed. Freeze-dried samples were ground into a fine powder using a cyclone sample mill (UD Corporation, Boulder, $\mathrm{CO}$ ) and a Wiley mill (Arthur H. Thomas Co., Philadelphia, PA). The GSL analysis for all the biofumigant crops was performed by a research collaborator at University of Tennessee, Knoxville. The protocol is described by Barickman et al. (2014).

On 11 Nov., the remaining mustard crops in the field were chopped using a flail mower (John Deere, Moline, IL) to ensure tissue disruption and incorporated into the soil using a tractor-pulled rototiller $\left(\mathrm{BEFCO}^{\circledR}\right.$,
Rocky Mount, NC). Care was taken to ensure that each crop remained in its respective block and did not mix with other treatments or the buffers. On incorporation into the soil, beds were reshaped and the field was sprinkler-irrigated to ensure hydrolysis and trap volatile biofumigant compounds in the soil matrix. The entire biofumigant incorporation process took $\approx 6 \mathrm{~h}$.

On 8 Dec., broccoli samples were collected in the same fashion as the mustard samples. Broccoli treatment incorporation was delayed as a result of slower biomass production compared with the mustard treatments and to allow more time for growth and development. Fresh and dry weights of all samples were taken and representative subsamples were collected and lyophilized as previously described. On 12 Dec., the broccoli treatment blocks were chopped and tilled. The bare soil treatments were also tilled at this time, and all treatments were sprinkler-irrigated.

Before seeding the primary crop of green chile pepper (Capsicum annuum 'AZ-20'), soil samples were collected from the center row of each treatment block on 5 Mar. 2012 at a depth of $20.32 \mathrm{~cm}$. Chile pepper plots were overlaid on the same location as the biofumigant treatments from the previous fall. Beds were reshaped, and 1.6-cm drip tape $\left(\mathrm{TORO}^{\circledR}\right.$, Bloomington, $\left.\mathrm{MN}\right)$ was installed at $15-\mathrm{cm}$ depth on 2 Mar. before the chile pepper was direct-seeded on 28 Mar. 2012 at an approximate rate of $4.5 \mathrm{~kg} \cdot \mathrm{ha}^{-1}$ using a vacuum precision planter (John Deere, Moline, IL). As a result of the presence of darkling beetle (Eleodes sp.; discovered 26 Apr. 2012) and unseasonably cool weather, germination was reduced. To establish a new stand, the beds were tilled and reshaped, and chile pepper was reseeded at the original rate with the same planter on 3 May 2012. Although not permitted in certified organic systems, Thiamethoxam insecticide was applied at the time of seeding (Syngenta Crop Protection Inc., Wilmington, DE) to prevent further insect damage. On 15 May, the top $3 \mathrm{~cm}$ of soil were removed (decapped) from all the rows to ensure seedling emergence. This soil moisture conservation practice is commonplace in southern New Mexico (Bosland and Walker, 2004).

Starting on 6 June, stand establishment within each block and treatment was measured and evaluated every 2 weeks until harvest. Chile plants were not thinned. On 22 June and 3 Aug., chile plants were fertilized with fish emulsion $(5 \mathrm{~N}-1 \mathrm{P}-1 \mathrm{~K}$; Lilly Miller ${ }^{\circledR}$ Alaska) at a rate of $34 \mathrm{~L}$ liquid fertilizer/4350 L water/ha. Fish emulsion (2N-4P-0.5K; Neptune's Harvest Fish Fertilizer; Ocean Crest Seafoods Inc., Gloucester, MA) was applied on 9 July, 20 July, 9 Aug., 17 Aug., and 22 Aug. The change in fertilizer source midseason was the result of an organic certification labeling change. Weeds were controlled by hand and mechanical cultivation as needed.

It is common practice to conduct multiple harvests of green, fleshy chile pepper pods to accommodate their staggered development (Bosland and Walker, 2004). This study only had one harvesting event. On 30 Aug., chile pepper pods were harvested from two randomly selected 3-m sections of each treatment block. Plants were completely stripped of their fruit and chile pods were separated into four categories: mature green, red, non-marketable, and immature pods. Above-ground biomass was also collected from the same chile plants that were stripped of their pods, and fresh and dry weights were collected. Soil samples were collected in all 25 treatment blocks on 31 Aug. from the same randomized locations where chile plants were stripped and biomass was collected.

Year 2. The experimental methods were repeated for Year 2 (2012-13) with the following changes. 'Arcadia' broccoli was seeded into flats of 72 cells on 6 Aug. 2012 and grown in a lath house. On 23 Aug. broccoli plants were sprayed with a biological insecticide (Bacillus thuringiensis; Garden Safe, Bridgeton, MO) to minimize cabbage looper (Trichoplusia ni) damage. Broccoli was fertilized using fish emulsion ( $2 \mathrm{~N}-4 \mathrm{P}-0.5 \mathrm{~K}$; Neptune's Harvest Fish Fertilizer) on 6 Sept., 17 Sept., 25 Sept., and 1 Oct. Broccoli plants were transplanted on 2 Oct. and then hand-watered in the field.

Mustards were broadcast-seeded on 14 Sept. using peat-based growing mix (Metro$\mathrm{Mix}^{\circledR}$; SunGro Horticulture Canada Ltd., Seba Beach, Alberta, Canada), similar to Year 1. The invasive Bagrada bug (Bagrada hilaris), a piercing-sucking insect pest that is new to New Mexico, was observed in the field for the first time on 18 Oct., but only minor damage was observed on the crop. Approximately $317 \mathrm{~kg} \cdot \mathrm{ha}^{-1}$ of fertilizer (10N-0P-6K; Ringer ${ }^{\circledR}$ Lawn Restore ${ }^{\circledR}$ ) was applied to the top of all beds, and all treatments were then sprinkler-irrigated on 22 Oct.

All biofumigant treatment samples were collected on $17 \mathrm{Dec}$., and the sampling protocol was the same as Year 1. Flail mowing, incorporation, bed-shaping, and sprinkle irrigation (to cap the field) all occurred on 18 Dec. Samples were oven-dried for $10 \mathrm{~d}$ at $40{ }^{\circ} \mathrm{C}$ and subsamples were stored in a freezer at $-20{ }^{\circ} \mathrm{C}$ before being lyophilized. Freeze-dried subsamples were then ground and sent for glucosinolate analysis as described in Year 1.

Drip tape $(1.6 \mathrm{~cm}$; T-systems, San Diego, CA) was laid and beds were shaped on 27 Feb. 2013 in preparation for Year 2 of chile pepper seeding. The field was flagged to mark the exact locations of the treatments as the previous season, and 25 soil samples (one from each treatment block) were collected on 12 Mar. As a result of the closure of the on-campus laboratory (SWAT), a different off-campus soil testing facility was selected (A\&L Plains Laboratories, Inc., Lubbock, TX). All soil samples from Mar. 2013 until the end of the study were sent to that facility.

'AZ-20' chile pepper seed was seeded on $11 \mathrm{Apr}$. at $11.21 \mathrm{~kg} \cdot \mathrm{ha}^{-1}$ using a Kincaid JD 4 Row Precision cone planter (Kincaid 
Equipment Manufacturing, Haven, KS), and all plots were then drip-irrigated. No insecticide was applied at planting or throughout the season. Two weeks after seeding, $\approx 3 \mathrm{~cm}$ of topsoil was decapped. Initial stand establishment was measured only once on 4 June, and chile pepper plants were thinned into clusters of three to four plants uniformly spaced $\approx 25 \mathrm{~cm}$ apart on 10 June (Walker, 2009). Beginning on 14 June, chile pepper plants were fertilized weekly until harvest with fish emulsion (3N-3P-0K; Organic Gem Fish Fertilizer; Advanced Marine Technologies, New Bedford, MA) at a rate of $34 \mathrm{~L}$ liquid fertilizer/4350 L water/ha.

On 21, 22, and 23 Aug., chile pepper pods were harvested and sorted. Above-ground biomass was collected from these same chile plants on 23 and 26 Aug., and fresh and dry weights were measured like in Year 1. Soil samples were collected on 3 Sept. in the same randomized locations as the chile pepper sampling. The same sampling methods and protocol were used as in Year 1.

Nematode studies. A seedling establishment study of the biofumigant crops in the presence of nematodes began in the greenhouse on 17 Apr. 2013. It was a completely randomized design with six replications. The control consisted of plastic pots (diameter $=$ $25.4 \mathrm{~cm}$, height $=22.9 \mathrm{~cm}$ ) containing uninoculated soil and seeded with each of the following treatments: 'Caliente 61', 'Caliente 199', and 'Pacific Gold'. Immediately before biofumigants were seeded, each pot was inoculated with $\approx 106,400 \mathrm{RKN}$ (Meloidogyne incognita) eggs that were collected from the roots of living tomato plants (Lycopersicon esculentum). The seeding rate for each pot was the same as that used in the field study $\left(6.74 \mathrm{~kg} \cdot \mathrm{ha}^{-1}, 11.23 \mathrm{~kg} \cdot \mathrm{ha}^{-1}\right.$, and $6.74 \mathrm{~kg} \cdot \mathrm{ha}^{-1}$ ). 'Caliente 61 ' and 'Pacific Gold' were seeded at $0.034 \mathrm{~g} / \mathrm{pot}$ and 'Caliente 199' was seeded at $0.057 \mathrm{~g} / \mathrm{pot}$. Plants were grown under an average greenhouse temperature of $27{ }^{\circ} \mathrm{C}$ with ambient light, once daily irrigation, and weekly fertilization of $20 \mathrm{~N}-20 \mathrm{P}-20 \mathrm{~K}$ synthetic fertilizer. Newly emerged biofumigant seedlings were counted in each pot 5, 7, 9, 13, and $16 \mathrm{~d}$ after planting. The seedling establishment study concluded on 7 May ( $21 \mathrm{~d}$ after planting). Fresh and dry weights of all biofumigant plant biomass (shoots and roots together) were collected and weighed.

On 15 Apr. 2013, the RKN host assay began in the same greenhouse, under the same conditions. Pots (diameter $=6.35 \mathrm{~cm}$, height $=25.4 \mathrm{~cm}, 656 \mathrm{~mL}$ volume; Deepots $^{\mathrm{TM}}$; Hummert International, Earth City, MO) were filled with loamy sand media and then seeded with the following treatments: 'Arcadia' broccoli, 'Caliente 61', 'Caliente 199', 'Pacific Gold', 'Boss' oilseed radish (Raphanus sativus var. oleifera), and 'Rutgers' tomato. Oilseed radish and tomato were used in the assay as established non-host and host controls for comparison, respectively (Westphal, 2011). Each pot was an experimental unit and was seeded with three seeds and then thinned to one seedling

Table 1. Year 1 (2011-12) pH and soil organic matter (SOM) in a green chile pepper rotation with four biofumigant crops.

\begin{tabular}{lccccc}
\hline & \multicolumn{2}{c}{ Spring 2012 } & & \multicolumn{2}{c}{ Fall 2012 } \\
\cline { 2 - 3 } \cline { 5 - 6 } Treatment & Mean pH & Mean SOM & & Mean pH & Mean SOM \\
\hline Control & $7.70 \pm 0.06 \mathrm{a}^{\mathrm{x}}$ & $0.94 \pm 0.02 \mathrm{~b}$ & & $8.00 \pm 0.14$ & 0.030 .03 \\
Broccoli & $7.62 \pm 0.02 \mathrm{ab}$ & $0.95 \pm 0.01 \mathrm{~b}$ & & $8.20 \pm 0.13$ & $0.46 \pm 0.02$ \\
Caliente 61 & $7.54 \pm 0.05 \mathrm{bc}$ & $1.00 \pm 0.04 \mathrm{~b}$ & & $8.00 \pm 0.05$ & $0.48 \pm 0.04$ \\
Caliente 199 & $7.50 \pm 0.04 \mathrm{c}$ & $1.02 \pm 0.04 \mathrm{~b}$ & & $8.12 \pm 0.09$ & $0.46 \pm 0.02$ \\
Pacific Gold & $7.44 \pm 0.02 \mathrm{c}$ & $1.12 \pm 0.04 \mathrm{a}$ & & $8.14 \pm 0.04$ & $0.44 \pm 0.05$ \\
\hline
\end{tabular}

${ }^{\mathrm{z}}$ Spring 2012 soil sample results represent the soil because it was after incorporation of the biofumigant crops, but before seeding the chile pepper.

${ }^{\mathrm{y}} \mathrm{Fall} 2012$ soil sample results represent the soil because it was after harvesting the chile pepper, but before tilling or seeding the biofumigant crops.

${ }^{x}$ Mean value \pm SE. Any two means within a column not followed by the same letter are significantly different (least significant difference) at $P \leq 0.05$. Five replications in each treatment.

after emergence. There were 10 replications for each treatment. After plants were established, the soil was inoculated with 2000 eggs of RKN at 2.5-cm depth on 1 May. The host assay was ended on 19 June 2013, $49 \mathrm{~d}$ after inoculation (cumulative soil heat units = $683)$. Forty-five d $(\approx 675$ cumulative heat units) is the standard interval used to evaluate host suitability to one generation of RKN (Hussey and Janssen, 2002), but harvest was delayed $4 \mathrm{~d}$ as a result of cooler than average soil temperatures in the greenhouse. The heat tolerance of RKN is dependent on both temperature and time. The greenhouse air temperature ranged from 17 to $44{ }^{\circ} \mathrm{C}$ during the assay, reflecting normal June diurnal air temperature fluctuations in southern New Mexico. However, RKN development is governed by soil temperatures, which are much more moderate.

The plant biomass of all treatments was collected, separated into root or shoot material, dried in an oven at $65^{\circ} \mathrm{C}$ for 1 week, and weighed. The RKN eggs were collected and counted using the methods described by Hussey and Barker (1973). A reproductive factor (RF) value was calculated for each treatment: the number of eggs recovered at the end of the study divided by the initial inoculum level (Oostenbrink, 1966).

Statistical analysis. The parameters measured in this experiment were designed to evaluate the effects of biofumigant crop residues on soil characteristics and chile pepper biomass and yield. The biofumigant crops themselves were also evaluated by quantifying biomass production and glucosinolate levels. Analysis was conducted on Year 1 and Year 2 data separately. All data were subjected to statistical analysis using the Statistical Analysis System (SAS) Version 9.3 statistical software (SAS Institute Inc., Cary, NC). Biofumigant vegetative biomass, GSL concentrations, chile pod yield, chile pepper vegetative biomass, stand count, $\mathrm{SOM}, \mathrm{pH}$, root and shoot biomass from the host assay, and biofumigant biomass from the emergence study data were all analyzed using an analysis of variance test (ANOVA). Red chile pepper pods in Year 1 had unequal variance and were therefore reanalyzed using a mixed model. Least significant differences $(P \leq 0.05)$ were used to separate means when ANOVA tests were significant.
Table 2. Year 1 (2011-12) biofumigant dry biomass production in green chile pepper rotation system

\begin{tabular}{lc}
\hline Treatment & Mean biomass $(\mathrm{kg} / \mathrm{plot})^{\mathrm{z}}$ \\
\hline Broccoli & $0.39 \pm 0.08 \mathrm{c}^{\mathrm{y}}$ \\
Caliente 61 & $1.09 \pm 0.19 \mathrm{~b}$ \\
Caliente 199 & $1.26 \pm 0.06 \mathrm{ab}$ \\
Pacific Gold & $1.44 \pm 0.17 \mathrm{a}$ \\
\hline
\end{tabular}

${ }^{\mathrm{z}}$ Samples collected from $1-\mathrm{m}^{2}$ area

${ }^{y}$ Mean value $\pm \mathrm{SE}$. Any two means within a column not followed by the same letter are significantly different (least significant difference) at $P \leq 0.05$. Five replications in each treatment.

Nematode host assay data, including RF values and root and shoot biomass, were reanalyzed with a negative binomial distribution as a result of unequal variances; the residual plot showed that variances were a function of the means. A negative binomial distribution takes these factors into account. Least squares means was used to perform pairwise comparisons between treatments. The emergence study was analyzed using ANOVA and a normal distribution because the variances were equal and were not a function of the means.

\section{Results and Discussion}

Year 1. After incorporating biofumigants, soil in the 'Pacific Gold' and 'Caliente 199' plots had the lowest $\mathrm{pH}$ of all the treatments (7.44 and 7.50, respectively; Table 1). This is desirable particularly in southern New Mexico where soils are alkaline and a shift to a more neutral $\mathrm{pH}$ would be beneficial (Flynn, 2012). The $\mathrm{pH}$ of the soil in broccoli and control plots was significantly higher (7.62 and 7.70, respectively) than 'Pacific Gold' and 'Caliente 199' (Table 1). SOM was significantly higher in 'Pacific Gold' plots $(1.12 \%)$ than all other treatments (Table 1$)$.

Broccoli produced the lowest total biomass of all the biofumigant treatments (Table 2) likely because it was transplanted later in the season and did not have sufficient time to mature before the late fall incorporation of the biofumigants. This result was not unexpected, but could be avoided by earlier seeding and, therefore, earlier transplanting into the field. Seeding the broccoli a month earlier would have made it possible to transplant the broccoli at the same time the mustards are seeded in the field. 
Table 3. Year 1 (2011-12) separate glucosinolate (GSL) functional group and total mean concentrations in the biofumigant crop tissues before incorporation into the soil.

\begin{tabular}{lcccc}
\hline & \multicolumn{3}{c}{ Mean GSL concentrations $\left(\mu \mathrm{mol} \cdot \mathrm{g}^{-1}\right.$ of tissue $)$} \\
\cline { 2 - 5 } Treatment & Aliphatic & Aromatic & Indolyl & Total mean \\
\hline Broccoli & $20.37 \pm 7.71^{\mathrm{z}}$ & $2.00 \pm 0.42$ & $13.01 \pm 2.31$ & $35.38 \pm 6.68$ \\
Caliente 61 & $34.94 \pm 7.64$ & $1.37 \pm 0.56$ & $12.03 \pm 1.42$ & $49.14 \pm 9.26$ \\
Caliente 199 & $57.50 \pm 3.60$ & $0.86 \pm 0.50$ & $13.68 \pm 1.51$ & $72.05 \pm 4.18$ \\
Pacific Gold & $44.90 \pm 3.65$ & $1.01 \pm 0.40$ & $11.74 \pm 1.82$ & $57.65 \pm 5.13$ \\
\hline
\end{tabular}

${ }^{2}$ Mean value \pm SE. Not significant at $P \leq 0.05$. Five replications in each treatment.

Table 4. Year 1 (2011-12) chile pepper dry vegetative biomass production grown in rotation with four different biofumigant crops

\begin{tabular}{lc}
\hline Treatment & Mean biomass $(\mathrm{kg} / \mathrm{plot})^{\mathrm{z}}$ \\
\hline Control & $0.54 \pm 0.10^{\mathrm{y}}$ \\
Broccoli & $0.55 \pm 0.13$ \\
Caliente 61 & $0.47 \pm 0.09$ \\
Caliente 199 & $0.65 \pm 0.08$ \\
Pacific Gold & $0.64 \pm 0.05$ \\
\hline
\end{tabular}

${ }^{\mathrm{z}}$ Samples collected from $1.5-\mathrm{m}^{2}$ area.

${ }^{\mathrm{y}}$ Mean value $\pm \mathrm{SE}$. Not significant at $P \leq 0.05$. Five replications in each treatment.

Neither the separate GSL group concentrations (aliphatic, aromatic, indolyl) nor the total GSL concentrations were significantly different among biofumigant treatments (Table 3). However, the average GSL values were comparable to what has been shown in previous studies. Kirkegaard and Sarwar (1998) reported 14 different $B$. juncea entries as having a total GSL range of 1.4 to 21.7 $\mu \mathrm{mol} \cdot \mathrm{g}^{-1}$ in the shoots at the time of flowering. The roots of those same entries were also analyzed and had a range of 4.6 to 14.5 $\mu \mathrm{mol} \cdot \mathrm{g}^{-1}$. The highest of these values is still lower than any of the average GSL values found in this study (Table 3), suggesting potential for pathogen suppression. Kushad et al. (1999) evaluated 50 different cultivars of broccoli and reported that the highest total GSL content from all the cultivars was $31.4 \mu \mathrm{mol} \cdot \mathrm{g}^{-1}$. This value is similar to the average broccoli GSL concentration in Year 1 of this study, which was $35.38 \mu \mathrm{mol} \cdot \mathrm{g}^{-1}$ (Table 3). 'Caliente 199' showed the most potential as a biofumigant in Year 1 with the second highest biomass production (1.26 kg/plot; Table 2) and the highest GSL concentration $\left(72.05 \mu \mathrm{mol} \cdot \mathrm{g}^{-1}\right.$; Table 3$)$.

There were no significant differences in chile pepper stand, biomass production (Table 4), or marketable green pod yield (Table 5) among treatments. The only differences observed were in the red pod yields between treatments. 'Pacific Gold' and 'Caliente 199' produced the highest red pod yield, and both were significantly higher than the control (Table 5). These results were not unexpected because other studies have shown that the beneficial effects of cover crops are often not observed for several years. SOM, in particular, accumulates very slowly (Sarrantonio, 2007) and may require additional soil amendments and modified cultivation practices. There were no significant differences in soil $\mathrm{pH}$ or organic matter among treatments after growing chile in the fall of 2012 (Table 1). After growing a cash crop and cultivating with no additional organic matter inputs, it is not unusual for the temporary SOM increases to be depleted (Sarrantonio, 2007).

Year 2. As a result of the closure of the SWAT laboratory, in Year 2, a different soil testing facility was used. SWAT laboratory used the Walkley-Black dichromate method for SOM analysis and a saturated paste procedure for soil $\mathrm{pH}$ analysis. The second, off-campus facility used a dichromate method for SOM analysis and a 1:1 method for $\mathrm{pH}$ analysis (Coleman, 2013, personal communication). 1:1 extracts for $\mathrm{pH}$ usually produce quite different results than those of saturated paste. The $\mathrm{pH}$ in a 1:1 extract is usually higher (Flynn, 2013, personal communication). Although both laboratories used a dichromate method for organic matter analysis, there may have been different amounts of sulfuric acid added during the oxidation process, which may account for differences between years (Flynn, 2013, personal communication; Tables 1 and 6). Reported values of SOM and $\mathrm{pH}$ for Mar. 2013 until the end of the study are, therefore, higher and should not be compared with previous values from the first analysis conducted using different procedures by another laboratory.

In the spring of Year 2, soil in the 'Caliente 199' and 'Caliente 61' treatment plots had the lowest $\mathrm{pH}$ (8.22 and 8.28, respectively) (Table 6). The soil in the control plots had the highest $\mathrm{pH}(8.58)$ but was not significantly different from soil in broccoli treatments (8.46). Soil organic matter differences among treatments were not significant likely as a result of delayed planting, low biofumigant biomass production, and high variances (Table 6).

'Caliente 199' had the highest aliphatic and aromatic GSLs and was significantly higher than those of broccoli or 'Caliente 61' (Table 7). ITCs from aromatic GSLs have been shown to be more toxic to soilborne pathogens, but the effects vary from pathogen to pathogen (Kirkegaard and Sarwar, 1998). Broccoli had significantly higher indolyl GSL concentrations than all other treatments (Table 7), but non-ITC-liberating GSLs are predominantly from indolyl GSLs (Gimsing and Kirkegaard, 2006). 'Caliente 199' tissues had the highest total GSL levels $\left(50.32 \mu \mathrm{mol} \cdot \mathrm{g}^{-1}\right.$ of tissue) and was significantly higher than 'Caliente 61' and broccoli treatments (38.39 and $20.20 \mu \mathrm{mol} \cdot \mathrm{g}^{-1}$ of tissue, respectively) (Table 7). Similar to Year 1, the GSL content in the biofumigants was comparable to other studies. Biofumigant vegetative biomass production values were not significantly different from each other (Table 8). However,
'Caliente 199' still showed the most biofumigant potential with the highest biomass production $(0.82 \mathrm{~kg} / \mathrm{plot}$; Table 8$)$, equal to 'Pacific Gold', the highest total GSL concentration (50.32 $\mu \mathrm{mol} \cdot \mathrm{g}^{-1}$; Table 7 ), and the highest concentration of GSLs in the aliphatic and aromatic functional groups (36.35 $\mu \mathrm{mol} \cdot \mathrm{g}^{-1}$ and $6.17 \mu \mathrm{mol} \cdot \mathrm{g}^{-1}$, respectively; Table 7).

Like in Year 1, there were no significant differences in chile pepper stand, biomass production (Table 9), or pod yield among treatments (Table 10) in Year 2. This suggests there was no allelopathic effect or phytotoxicity from the biofumigant treatments.

In the fall of Year 2, soil in the 'Caliente 61 ' treatments had the lowest $\mathrm{pH}(8.22)$ but was not significantly different from the soil in 'Caliente 199' treatments (8.32) or the control plots (8.30) (Table 6). However, there were no significant differences in SOM among treatments (Table 6). This result was expected because there was low biofumigant biomass production in the fall, and there was no significant difference in SOM among treatments in the soil samples collected earlier in the spring before chile peppers were seeded.

Nematode studies. In the RKN host assay, broccoli had the lowest egg count and RF value $(0.45)$ of all the treatments (Table 11). An RF value of less than 1.0 is desirable (Oostenbrink, 1966) because it indicates that the crop does not support reproduction of RKN at a rate sufficient to increase the parasite population. The RF values for the three mustards were significantly higher than broccoli and oilseed radish, significantly lower than tomato (susceptible control), but were not significantly different from each other (Table 11). Broccoli was the poorest host for RKN and could be recommended to a grower with nematode pressure in the field to reduce RKN populations. 'Caliente 61', 'Caliente 199', and 'Pacific Gold' should not be recommended to a grower that has nematode pressure in the field because RKN populations multiplied under the growth of these mustard crops in this greenhouse host assay and would likely increase overwintering nematode populations if planted as a fall biofumigant crop.

Root and shoot biomass of broccoli were greater than comparable biomass of mustards in the RKN host assay, but no conclusions can be drawn from these results without comparative data from non-inoculated plants (Table 11). Pathogenicity studies are needed to determine if 'Arcadia' broccoli, which is the least suitable host for RKN, exhibits greater root and shoot biomass production than the mustards in the presence of RKN. In the seedling establishment study, the three mustard crops showed stunted growth and development in the presence of RKN. All treatments in the non-inoculated pots had significantly higher biomass than the treatments in the inoculated pots (Table 12). Even from the early stages of germination 
Table 5. Year 1 (2011-12) chile pepper pod yield after being grown in rotation with four different biofumigant crops.

\begin{tabular}{lcccc}
\hline Treatment & Green $^{\mathrm{z}}$ & Fresh red & Immature & Non-marketable \\
Control & $1.88 \pm 0.60^{\mathrm{y}}$ & $0.06 \pm 0.03 \mathrm{c}$ & $0.56 \pm 0.10$ & $0.77 \pm 0.21$ \\
Broccoli & $1.66 \pm 0.76$ & $0.08 \pm 0.03 \mathrm{bc}$ & $0.61 \pm 0.09$ & $0.73 \pm 0.20$ \\
Caliente 61 & $1.05 \pm 0.26$ & $0.11 \pm 0.04 \mathrm{abc}$ & $0.60 \pm 0.12$ & $0.64 \pm 0.15$ \\
Caliente 199 & $2.09 \pm 0.38$ & $0.15 \pm 0.02 \mathrm{ab}$ & $0.79 \pm 0.11$ & $1.00 \pm 0.18$ \\
Pacific Gold & $1.13 \pm 0.09$ & $0.17 \pm 0.04 \mathrm{a}$ & $0.73 \pm 0.07$ & $0.94 \pm 0.10$ \\
\hline
\end{tabular}

${ }^{\mathrm{z}}$ Samples collected from $1.5-\mathrm{m}^{2}$ area; values reported in $\mathrm{kg} / \mathrm{plot}$.

${ }^{y}$ Mean value \pm SE. Any two means within a column not followed by the same letter are significantly different (least significant difference) at $P \leq 0.05$. Five replications per treatment.

Table 6. Year 2 (2012-13) pH and soil organic matter (SOM) in a green chile pepper rotation system with four biofumigant crops.

\begin{tabular}{|c|c|c|c|c|}
\hline \multirow[b]{2}{*}{ Treatment } & \multicolumn{2}{|c|}{ Spring $2013^{z}$} & \multicolumn{2}{|c|}{ Fall $2013^{y}$} \\
\hline & Mean pH & Mean SOM & Mean pH & Mean SOM \\
\hline Control & $8.58 \pm 0.07 \mathrm{a}^{\mathrm{x}}$ & $0.56 \pm 0.04$ & $8.30 \pm 0.05 \mathrm{ab}$ & $0.46 \pm 0.04$ \\
\hline Broccoli & $8.46 \pm 0.04 \mathrm{ab}$ & $0.44 \pm 0.07$ & $8.38 \pm 0.05 a$ & $0.48 \pm 0.02$ \\
\hline Caliente 61 & $8.28 \pm 0.06 \mathrm{c}$ & $0.40 \pm 0.08$ & $8.22 \pm 0.05 b$ & $0.46 \pm 0.02$ \\
\hline Caliente 199 & $8.22 \pm 0.02 \mathrm{c}$ & $0.38 \pm 0.06$ & $8.32 \pm 0.06 \mathrm{ab}$ & $0.44 \pm 0.02$ \\
\hline Pacific Gold & $8.34 \pm 0.07 b c$ & $0.56 \pm 0.05$ & $8.40 \pm 0.04 \mathrm{a}$ & $0.44 \pm 0.02$ \\
\hline
\end{tabular}

${ }^{\mathrm{z}}$ Spring 2013 soil sample results represent the soil because it was after incorporation of the biofumigant crops, but before seeding the chile pepper.

${ }^{\mathrm{y}}$ Fall 2013 soil sample results represent the soil as it was after harvesting the chile pepper, but before tilling or seeding the biofumigant crops.

${ }^{\mathrm{x}}$ Mean value $\pm \mathrm{SE}$. Any two means within a column not followed by the same letter are significantly different (least significant difference) at $P \leq 0.05$. Five replications per treatment.

Table 7. Year 2 (2012-13) separate glucosinolate (GSL) functional group and total mean concentrations from biofumigant tissue collected before incorporation into the soil.

\begin{tabular}{lccrc}
\hline & \multicolumn{4}{c}{ Mean GSL concentrations $\left(\mu \mathrm{mol} \cdot \mathrm{g}^{-1}\right.$ of tissue $)$} \\
\cline { 2 - 5 } Treatment & Aliphatic & Aromatic & Indolyl & Total mean \\
\hline Broccoli & $4.29 \pm 0.67 \mathrm{c}^{\mathrm{z}}$ & $1.77 \pm 0.58 \mathrm{c}$ & $14.14 \pm 1.22 \mathrm{a}$ & $20.20 \pm 1.46 \mathrm{c}^{\mathrm{z}}$ \\
Caliente 61 & $26.60 \pm 2.65 \mathrm{~b}$ & $3.64 \pm 0.42 \mathrm{bc}$ & $8.15 \pm 0.34 \mathrm{~b}$ & $38.39 \pm 3.26 \mathrm{~b}$ \\
Caliente 199 & $36.35 \pm 3.48 \mathrm{a}$ & $6.17 \pm 0.97 \mathrm{a}$ & $7.80 \pm 0.33 \mathrm{~b}$ & $50.32 \pm 3.86 \mathrm{a}$ \\
Pacific Gold & $29.14 \pm 2.58 \mathrm{ab}$ & $5.40 \pm 1.04 \mathrm{ab}$ & $8.60 \pm 0.31 \mathrm{~b}$ & $43.13 \pm 1.99 \mathrm{ab}$ \\
\hline
\end{tabular}

${ }^{2}$ Mean value \pm SE. Any two means within a column not followed by the same letter are significantly different (least significant difference) at $P \leq 0.05$. Five replications per treatment.

Table 8. Year 2 (2012-13) biofumigant dry biomass production in a green chile pepper rotation system.

\begin{tabular}{lc}
\hline Treatment & Mean biomass $(\mathrm{kg} / \mathrm{plot})^{\mathrm{z}}$ \\
\hline Broccoli & $0.31 \pm 0.07^{\mathrm{y}}$ \\
Caliente 61 & $0.76 \pm 0.12$ \\
Caliente 199 & $0.82 \pm 0.29$ \\
Pacific Gold & $0.82 \pm 0.28$ \\
\hline
\end{tabular}

${ }^{{ }^{2}}$ Samples collected from $1-\mathrm{m}^{2}$ area.

${ }^{\mathrm{y}}$ Mean value $\pm \mathrm{SE}$. Not significant at $P \leq 0.05$. Five replications per treatment.

Table 9. Year 2 (2012-13) chile pepper dry vegetative biomass in rotation with four biofumigant crops.

\begin{tabular}{lc}
\hline Treatment & Mean biomass $(\mathrm{kg} / \mathrm{plot})^{\mathrm{z}}$ \\
\hline Control & $1.16 \pm 0.26^{\mathrm{y}}$ \\
Broccoli & $0.95 \pm 0.28$ \\
Caliente 61 & $0.91 \pm 0.27$ \\
Caliente 199 & $0.94 \pm 0.19$ \\
Pacific Gold & $0.97 \pm 0.13$ \\
\hline
\end{tabular}

${ }^{\mathrm{z}}$ Samples collected from $1.5-\mathrm{m}^{2}$ area.

${ }^{\mathrm{y}}$ Mean value $\pm \mathrm{sE}$. Not significant at $P \leq 0.05$. Five replications per treatment.

and emergence, RKN appears to inhibit the growth of the three mustard biofumigants. Additional pathogenicity studies are needed to determine if these mustards would be
High biofumigant biomass production, similar to what was observed in Year 1 of this study, can produce both a temporary increase in SOM and a soil pH-buffering effect. Over time, an increase in SOM can produce higher cash crop yields as a result of greater soil productivity (Hartwig and Ammon, 2002). High GSL concentrations in the mustard tissues can result in high ITC concentrations in the soil, which have the ability to suppress soilborne pathogens, if present. Previous studies have suggested that greater than $100 \mathrm{nmol}$ of ITC/g of soil is sufficiently high to suppress soilborne pathogens (Gimsing and Kirkegaard, 2009). In Year 1, for example, 'Caliente 199' produced $\approx 440 \mathrm{nmol}$ of $\mathrm{GSL} / \mathrm{g}$ of soil. Even if only half of those GSLs are ITC-liberating, 'Caliente 199' would still be able to effectively suppress soilborne pests. However, Kirkegaard and Sarwar (1998) found that nearly all GSLs in $B$. juncea tissues were ITC-liberating. This is a good indication of the effectiveness of the $B$. juncea crops in this study for potential soilborne pathogen suppression.

Nematodes may be suppressed by the ITCs released by the disrupted tissue of the biofumigants (Douda et al., 2012), or the nematode population may be unable to reproduce as a result of the non-host suitability of a particular biofumigant crop (Pattinson et al., 2007). 'Arcadia' broccoli, in the host assay, reduced RKN populations without tissue disruption or ITC liberation in the soil.

Two of the mustard cultivars in this study, 'Caliente 199' and 'Pacific Gold', emerged as the top performing biofumigants. 'Caliente 199' treatment plots showed a more moderated soil $\mathrm{pH}$ in the spring of both Year 1 and Year 2, produced high biomass in Year 1, and showed the highest total GSL content in both years. The total GSL content of 'Caliente 199' was comparable with previously reported values from various Brassica species (Kirkegaard and Sarwar, 1998; Kushad et al., 1999). 'Caliente 199' also had the highest aliphatic GSLs in Year 1 and Year 2 and the highest aromatic GSLs in Year 2, although not significantly higher than 'Pacific Gold'. 'Pacific Gold' plots also produced a more moderated soil $\mathrm{pH}$ in the spring of both Year 1 and Year 2, produced the highest increase in SOM in Year 1, had the highest biomass in Year 1, and the highest aromatic GSLs in Year 1.

Biofumigation has the potential to positively impact various agricultural systems and be a viable, sustainable alternative to some conventional fumigation practices. In the semiarid southwest, biofumigation may help mitigate several of the soil-related problems that growers currently face such as low $\mathrm{SOM}$, high $\mathrm{pH}$, and pathogen pressure. Growers may be hesitant to adopt biofumigation in southern New Mexico because of limited access to water for agricultural purposes and additional fertilizer and labor costs. Growers need to be assured that the benefits of biofumigation can outweigh the costs of additional inputs. 
Table 10. Year $2(2012-13)$ chile pepper pod yield after being grown in rotation with four biofumigant crops.

\begin{tabular}{lcccc}
\hline Treatment & Green $^{\mathrm{z}}$ & Fresh red & Immature & Non-marketable \\
\hline Control & $1.71 \pm 0.92^{\mathrm{y}}$ & $0.32 \pm 0.07$ & $1.15 \pm 0.20$ & $1.21 \pm 0.53$ \\
Broccoli & $1.63 \pm 1.08$ & $0.36 \pm 0.11$ & $0.86 \pm 0.24$ & $0.86 \pm 0.36$ \\
Caliente 61 & $0.73 \pm 0.37$ & $0.52 \pm 0.17$ & $0.92 \pm 0.31$ & $1.12 \pm 0.47$ \\
Caliente 199 & $1.21 \pm 0.71$ & $0.64 \pm 0.22$ & $0.93 \pm 0.18$ & $1.02 \pm 0.41$ \\
Pacific Gold & $0.71 \pm 0.35$ & $0.50 \pm 0.18$ & $1.02 \pm 0.13$ & $0.78 \pm 0.30$ \\
\hline
\end{tabular}

${ }^{\mathrm{z}}$ Samples collected from $1.5-\mathrm{m}^{2}$ area; values reported in $\mathrm{kg} / \mathrm{plot}$.

${ }^{\mathrm{y}}$ Mean value $\pm \mathrm{SE}$. Not significant at $P \leq 0.05$. Five replications per treatment.

Table 11. Southern root-knot nematode (RKN) host assay root and shoot production and reproductive factor (RF) values of various biofumigant crops.

\begin{tabular}{lccr}
\hline Treatment & Root biomass $(\mathrm{g})$ & Shoot biomass $(\mathrm{g})$ & RF value $^{\mathrm{z}}$ \\
\hline Broccoli & $2.50 \pm 0.32 \mathrm{a}^{\mathrm{y}}$ & $4.07 \pm 0.18 \mathrm{a}$ & $0.45 \pm 0.08 \mathrm{a}$ \\
Caliente 61 & $0.34 \pm 0.05 \mathrm{~cd}$ & $2.49 \pm 0.22 \mathrm{~b}$ & $13.19 \pm 1.93 \mathrm{c}$ \\
Caliente 199 & $0.51 \pm 0.11 \mathrm{c}$ & $2.59 \pm 0.18 \mathrm{~b}$ & $21.34 \pm 5.55 \mathrm{c}$ \\
Pacific Gold & $0.27 \pm 0.05 \mathrm{~d}$ & $1.53 \pm 0.14 \mathrm{c}$ & $28.33 \pm 3.91 \mathrm{c}$ \\
Oilseed $(-)$ & $0.88 \pm 0.25 \mathrm{~b}$ & $2.94 \pm 0.51 \mathrm{~b}$ & $3.29 \pm 2.60 \mathrm{~b}$ \\
Tomato (+) & $0.92 \pm 0.10 \mathrm{~b}$ & $4.06 \pm 0.39 \mathrm{a}$ & $115.40 \pm 17.21 \mathrm{~d}$ \\
\hline
\end{tabular}

${ }^{2} \mathrm{RF}=$ no. of $\mathrm{RKN}$ eggs recovered/no. of initial inoculum.

${ }^{y}$ Mean value \pm SE. Any two means within a column not followed by the same letter are significantly different at $P \leq 0.05$. Test of differences used in a normal approximation. 10 replications per treatment. Initial inoculum $=2000 \mathrm{RKN}$ eggs.

Table 12. Biofumigant seedling biomass as affected by southern root-knot nematode in the seedling establishment study with biofumigant crops $21 \mathrm{~d}$ after seeding.

\begin{tabular}{lll}
\hline & \multicolumn{2}{c}{ Mean biomass $(\mathrm{g})$} \\
\cline { 2 - 3 } Treatment & Uninoculated & Inoculated \\
\hline Caliente 61 & $3.73 \pm 0.37 \mathrm{a}^{\mathrm{z}}$ & $1.51 \pm 0.51 \mathrm{~b}$ \\
Caliente 199 & $9.62 \pm 1.25 \mathrm{a}$ & $2.75 \pm 0.36 \mathrm{~b}$ \\
Pacific Gold & $4.98 \pm 1.03 \mathrm{a}$ & $2.37 \pm 0.50 \mathrm{~b}$ \\
\hline
\end{tabular}

${ }^{\mathrm{z}}$ Mean value $\pm \mathrm{SE}$. Any two means within a column not followed by the same letter are significantly different at $P \leq 0.05$. Six replications per treatment.

Root and shoot biomass collected together.

\section{Literature Cited}

Barickman, T.C., D.A. Kopsell, and C.E. Sams. 2014. Impact of selenium fertilization on glucosinolate concentrations in Arabidopsis thaliana and rapid-cycle Brassica oleracea. J. Plant Nutr. 37(3):343-356.

Bosland, P.W. and E.J. Votava. 2000. Disorders, diseases and pests, p. 162-180. In: Atherton, J. (ed.). Peppers: Vegetables and spice capsicums. CABI, Oxfordshire, UK

Bosland, P.W. and S. Walker. 2004. Growing chiles in New Mexico. New Mexico State Coop. Ext. Serv. Guide H-230.

Brown, P.D. and M.J. Morra. 1997. Control of soilborne plant pests using glucosinolate-containing plants. Adv. Agron. 61:167-231.

Collins, H.P., P.B. Hamm, A. McGuire, E. Riga, A. Alva, and R.A. Boydston. 2006. Soil microbial, fungal, and nematode responses to soil fumigation and cover crops under potato production. Biol. Fertil. Soils 42:247-257.

Douda, O., M. Zouhar, E. Novakova, and J. Mazakova. 2012Alternative methods of carrot (Daucus carota) protection against the northern root knot nematode (Meloidogyne hapla). Acta Agriculturae Scandinavica Section B-Soil and Plant Sci. 62:91-93.
Flynn, R. 2012. Appropriate analysis for New Mexico soils. New Mexico State University Coop. Ext. Serv. Guide A-146.

Gimsing, A.L. and J.A. Kirkegaard. 2006. Glucosinolate and isothiocyanate concentration in the soil following incorporation of Brassica biofumigants. Soil Biol. Biochem. 38:2255-2264.

Gimsing, A.L. and J.A. Kirkegaard. 2009. Glucosinolates and biofumigation: Fate of glucosinolates and their hydrolysis products in the soil. Phytochem. Rev. 8:299-310.

Goldberg, N.P. 2001. Chile pepper diseases. New Mexico State University Coop. Ext. Serv. Circ. 549.

Hartwig, N.L. and H.U. Ammon. 2002. Cover crops and living mulches. Weed Sci. 50:688-699.

Hussey, R.S. and K.R. Barker. 1973. A comparison of methods of collecting inocula for Meloidogyne spp., including a new technique. Plant Dis. Rpt. 57:1025-1028.

Hussey, R.S. and G.J.W. Janssen. 2002. Root-knot nematodes: Meloidogyne species, p. 43-70. In: Starr, J.L., R. Cook, and J. Bridge (eds.). Plant resistance to parasitic nematodes. CABI, Wallingford, UK.

Kirkegaard, J.A., J.N. Matthiessen, T.W. Wong, A. Mead, M. Sarwar, and B.J. Smith. 1999. Exploiting the biofumigation potential of Brassicas in farming systems. Proc. X Intl. Rapeseed Congr. gation potential of brassicas. I. Variation in glucosinolate profiles of diverse field-grown brassicas. Plant Soil 201:71-89.

Kushad, M.M., B.P. Klein, M.A. Wallig, E.H. Jeffery, A.F. Brown, and A.C. Kurilich. 1999. Variation of glucosinolates in vegetable crops of Brassica oleracea. J. Agr. Food Chem. 47:1541-1548.

Magdoff, F. and H. Van Es. 2009. Building soils for better crops: Sustainable soil management. $3^{\text {rd }}$ Ed. Sustainable Agriculture Research and Education, Waldorf, MD.

Martin, F.N. 2003. Development of alternative strategies for management of soilborne
Kirkegaard, J.A. and M. Sarwar. 1998. Biofumi- pathogens currently controlled with methyl bromide. Phytopathol. 41:325-350.

Matthiessen, J.N. and J.A. Kirkegaard. 2006. Biofumigation and enhanced biodegradation: Opportunity and challenge in soilborne pest and disease management. Crit. Rev. Plant Sci. 25:235-265.

Mattner, S.W., D.J. Wren, D. Allen, A.L. Shanks, I.J. Porter, and R.K. Gounder. 2008. Factors that impact on the ability of biofumigants to suppress fungal pathogens and weeds of strawberry. Crop Prot. 27:1165-1173.

McGuire, A.M. 2003. Mustard green manures replace fumigant and improve infiltration in potato cropping system. Crop Mgt. 2(1). DOI: 10.1094/CM-2003-0822-01-RS.

Oostenbrink, M. 1966. Major characteristics between the relations between nematodes and plants. Meded. Landbouwhogesch. Wageningen 66-4.

Pattinson, A.B., C. Versteeg, S. Akiew, and J. Kirkegaard. 2007. Resistance of Brassicaceae plants to root-knot nematode (Meloidogyne spp.) in northern Australia. Intl. J. Pest Mgt. 52:53-62.

Ramirez, R.A., D.R. Henderson, E. Riga, L.A. Lacey, and W.E. Snyder. 2009. Harmful effects of mustard bio-fumigants on entomopathogenic nematodes. Biol. Control 48:147-154.

Sarrantonio, M. 2007. Building soil fertility and tilth with cover crops, p. 16-24. In: Clark, A. (ed.). Managing cover crops profitably. Sustainable Agriculture Network, College Park, MD.

Snapp, S.S., S.M. Swinton, R. Labarta, and D. Mutch. 2004. Evaluating cover crops for benefits, costs and performance within cropping system niches. Agron. 97:322-332.

Thomas, S.H. 1995. Managing nematodes on chile. New Mexico State Coop. Ext. Serv. Guide H-241.

Thomas, S.H., L.W. Murray, and M. Cardenas. 1995. Relationship of preplant population densities of Meloidogyne incognita to damage in three chile pepper cultivars. Plant Dis. 79:557559.

University of California Agriculture and Natural Resources. 2013. UC scientists continue the quest for alternatives to chemical fumigation. 11 June 2013. <http://ucanr.edu/?story=147>.

U.S. Department of Agriculture National Agricultural Statistics Service. Mar. 2014. Vegetables 2013 summary. June 2014. <http://usda.mannlib. cornell.edu/usda/current/VegeSumm/VegeSumm03-27-2014.pdf>.

U.S. Environmental Protection Agency. 2000. Methyl bromide (bromomethane). 12 Oct. 2011. <http://www.epa.gov/ttn/atw/hlthef/ methylbr.html>.

US-EPA. 2012. Implementation of risk mitigation measures for soil fumigant pesticides. 7 Aug. 2014. < http://www.epa.gov/pesticides/ reregistration/x-soil-fum-HOLD/>.

US-EPA. 2014. The phaseout of methyl bromide. 7 Aug. 2014. <http://www.epa.gov/ozone/mbr/>.

Walker, S.J. 2009. Red chile and paprika production in New Mexico. New Mexico State Coop. Ext. Serv. Guide H-257.

Walker, S.J., S.H. Thomas, and M.E. Uchanski. 2012. Evaluations of chloropicrin fumigants for management of soil-borne pathogens in chile (Capsicum annuum L.). New Mexico Chile Assn. 33:1-8.

Westphal, A. 2011. Sustainable approaches to the management of plant-parasitic nematodes and disease complexes. J. Nematol. 43:122-125. 